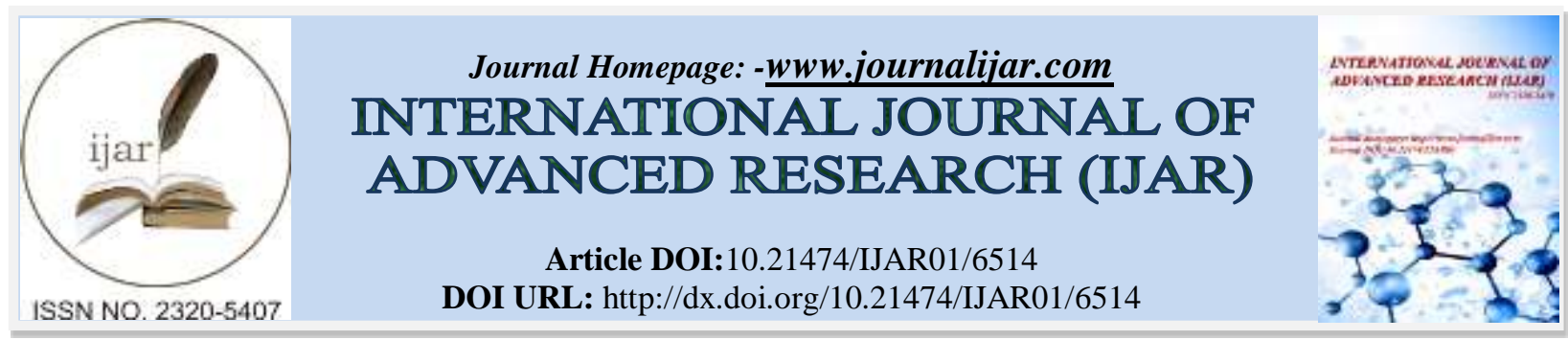

RESEARCH ARTICLE

\title{
ASSESSMENT OF PHYSICOCHEMICAL AND FUNCTIONAL PROPERTIES FROM HEART OF OIL PALM TREE (ELAEIS GUINEENSIS JACQ.) CONSUMED IN CÔTE D'IVOIRE.
}

\author{
Rosine Mihia Brou, Betty Meuwiah Faulet, "Gbocho Serge Elvis Ekissi, Thierry Martial Fankroma Koné and \\ Patrice Lucien Kouamé. \\ Laboratory of Biochemistry and Food Technology, University Nangui Abrogoua (Abidjan, Côte d'Ivoire), 02 BP \\ 801 Abidjan 02, Côte d'Ivoire.
}

\section{Manuscript Info}

Manuscript History

Received: 12 December 2017

Final Accepted: 14 January 2018

Published: February 2018

Keywords:-

Heart of oil palm tree, Elaeis guineensis, flours, Physicochemical, Functional properties.

\begin{abstract}
The heart of the oil palm tree (Elaeis guineensis Jacq.) is a vegetable, very little consumed in Côte d'Ivoire and unknown to the population. The aim of this study is to evaluate its nutritional potential in order to contribute to a wide consumption and valorization. Thus the physicochemical and functional properties of different parts (proximal, median, distal) of heart of oil palm tree were assessed. Some physicochemical results obtained are as follows: moisture $(5.87 \pm 0.01$ $10.83 \pm 1.16 \%)$, crude proteins $(10.7 \pm 0.66-13.12 \pm 0.69 \%)$, crude fiber $(21.98 \pm 0.02$ - $34.9 \pm 0.1 \%)$, ash $(6.91 \pm 0.07$ - 8.28 $\pm 0.51 \%)$, carbohydrates $(39.85 \pm 0.06-46.42 \pm 0.11 \%)$ and energy $(270.45 \pm 0.04-$ $33.65 \pm 0.01 \mathrm{kcal} / 100 \mathrm{~g})$. The major mineral is the Potassium $(1412 \pm 224.65$ - 1787.43 \pm 75.57$)$. Some functional properties studied are as follows: Bulk density $\left(0.54 \pm 0.01-0.57 \pm 0.01 \mathrm{~g} / \mathrm{cm}^{3}\right)$, Foam capacity $(26.31 \pm 0.72-31.61 \pm 0.54 \%)$, Water absorption capacity $(453.15 \pm 1.6$ - 568.7 $\pm 0.89 \%)$, Water solubility index $(25.4 \pm 0.28$ $30.25 \pm 0.21 \%)$, Paste clarity $(0.16-0.21 \%)$, Wettability (135.9 - 330 $\mathrm{sec})$. The physicochemical and functional properties of different parts (PP, MP, DP) from heart of oil palm tree core show significant differences $(\mathrm{P}<0.05)$.
\end{abstract}

Copy Right, IJAR, 2018,. All rights reserved.

\section{Introduction:-}

Wild edible plants play many roles in the life of populations. In Africa, thousands of wild plants are used daily by farming communities (Grivetti et al., 1987). These plants contribute substantially to the survival of populations by providing nutrients in their diet. They provide food in the form of fruits, leaves, roots, seeds and other plant parts, either raw or cooked (Shad et al., 2013). Among these plants, we can quote, rônier (Borassus aethiopum), coconut (Coco nucifera), raffia (Raffia sp.) and oil palm tree (Elaeis guineensis)

Oil palm tree (Elaeis guineensis Jacq.) is a monocotyledon of the Arecaceae family. It is widely grown for its fruits and seeds rich (palm oil) in oil for food and industrial use. For several years, this oil has become the main source of vegetable fats in the world market (Jacquemard, 2012). This oil is more used in food, soap making and cosmetology. Since $2006,1 \%$ of biodiesel was produced from palm oil. In 2010, it became the most consumed vegetable oil in the world (FAO, 2013). In tropical Africa, this plant occupies a predominant position in agricultural production, trade and fat consumption (Aholoukpe et al., 2013). 
Introduced in Côte d'Ivoire as part of the political of diversifying cash crops, the palm sector produced $400,000 \mathrm{t}$ of palm oil (FAO STAT, 2013) and has 215,000 hectares of palm grove (Hubert, 2010, CIRAD, 2017). Several food products come from the oil palm: heart of palm, fruits, mushrooms, palm wine, alcohol ... The heart of oil palm tree (internal part of the stem of the tree) is much appreciated by the populations for its aperitive and digestive virtues. In the consumption zones (south, south-west) in Côte d'Ivoire, the palm heart has a socio-cultural value. It is traditionally eaten as vegetables in sauces. Some use it as a beverage, others used it replace breast milk for the infant when the mother dies after childbirth. The heart of the oil palm tree, very difficult to obtain, is a popular vegetable of the populations. Because of its nutritional composition, it could cover several daily nutritional needs (Tabora et al., 1993). Unfortunately it's very little known to other peoples. Its biochemical composition remains unknown. The aim of this study is to evaluate the nutritional potential from the heart of oil palm tree in order to contribute to its valorization.

\section{Materials and Methods:-}

\section{Sample collection and preparation:-}

The biological material used is the heart of oil palm tree, collected in Soubré (West, Côte d'Ivoire). Put in a cooler to preserve its fresh state, they were transported to the Laboratory of Biochemistry and Food Technology of University of Nangui Abrogoua (Abidjan, Côte d'Ivoire) where study was conducted. The heart of oil palm tree (photography 1) were cut in three equal parts: proximal part (head of heart of oil palm tree), median part (middle) and distal part (tail of heart of oil palm tree) (Photography 1). Each part were peeled, cut in small slices $\left(4 \times 4 \times 4 \mathrm{~cm}^{3}\right)$ and washed with distilled water. Five hundred (500) g of slices in each lot were dried at $45^{\circ} \mathrm{C} \mathrm{during} 48 \mathrm{~h}$. The dried slices were ground and pass through sieve $(250 \mu \mathrm{m}$ size $)$. The obtained flour was kept for analysis.
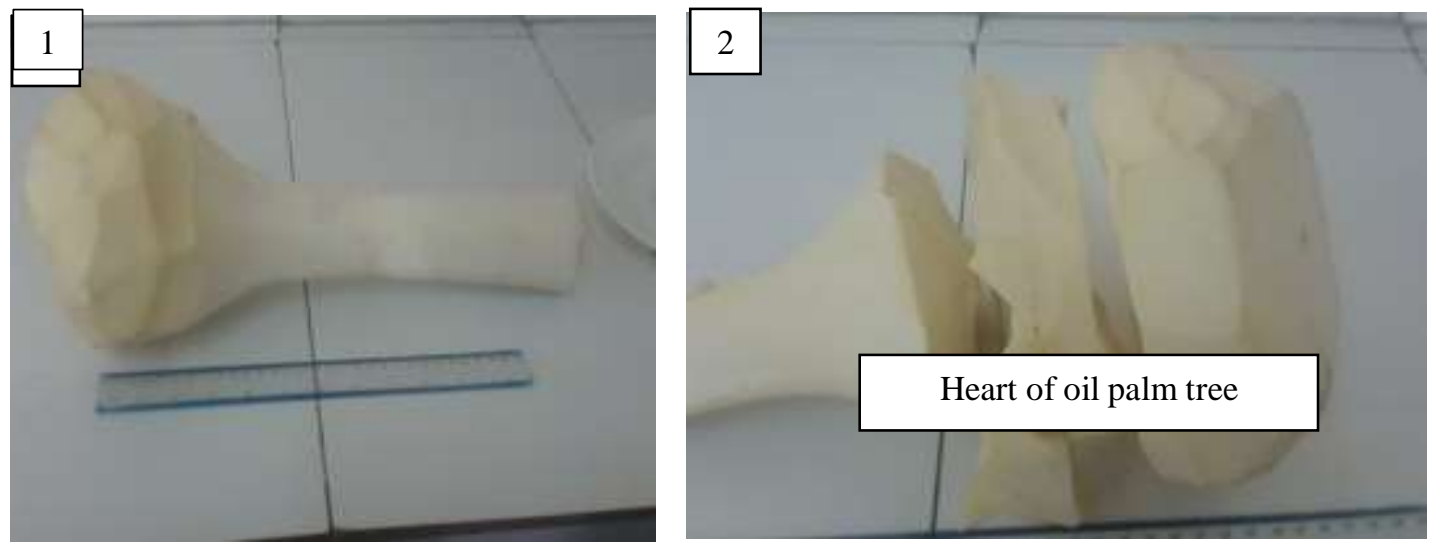

Photography 1:- Heart of oil palm tree (Elaeis guineensis Jacquin), 2- different parts of the heart of oil palm tree (A: proximal part (PP); B: median part (MP); C: distal part (DP)

\section{Proximate analysis:-}

Moisture content (on dry weigh basis) was determined on fresh sliced samples after oven drying at $105^{\circ} \mathrm{C}$ for $24 \mathrm{~h}$ according the procedure of AOAC (1990). Sugars were extracted from flours using $80 \%$ aqueous ethanol. Total sugars were determined using the method of phenol-sulfuric (Dubois et al., 1991). Reducing sugars were determined according to the method of Bernfeld (1955) using DNS. Crude fat was determined exhaustively extracting sample of flours in a soxhlet apparatus using anhydrous hexan as solvent. Nitrogen was determined by the Kjeldahl method reported by AOAC (1990) and crude protein content was subsequently calculated by multiplying the nitrogen content by a factor of 6.25. Ash content was determined by measurement of residues left after combustion in a furnace at $550^{\circ} \mathrm{C}$ for $8 \mathrm{~h}$ (AOAC, 1990). Fiber estimate was obtained from the loss in weight of dried residue following the digestion for fat-free samples with $1.25 \%$ each of sulfuric acid and sodium hydroxide solutions. Energy were obtained by the summation of multiplied mean values for protein, fat and carbohydrate by their respective Atwater factors, 4, 9 and 4 (Udosen, 1995). Carbohydrate were calculated using the following formulas $($ FAO, 2002): Carbohydrates $($ dry matter basis $)=100-(\%$ moisture $+\%$ proteins $+\%$ lipids $+\%$ ash $+\%$ fibers $)$ 


\section{Minerals analysis:-}

The mineral elements were analyzed after wet-ashing using the scanning electron microscope (SEM) with variable pressure (SEM FEG Zeiss Supra $40 \mathrm{VP}$ ). This SEM is equipped with an X-ray detector (Oxford Instruments) connected to an energy diffusion spectrometry (EDS) microanalyzer platform (Inca Cool Dry, without liquid nitrogen). About $10 \mathrm{mg}$ of the sample ash residue were applied evenly to a primed platform with double-sided adhesive carbon for analysis. To measure the content of chemical elements, the device performs a measurement of the transition energy of the electrons from electronic clouds of the $\mathrm{K}, \mathrm{L}$ and $\mathrm{M}$ series of atoms of the sample.

\section{Functional properties:-}

\section{Bulk density (BD):-}

The method described by Oladele and Ainaby (2007) was used for the determination of bulk density. $50 \mathrm{~g}$ from heart of oil palm tree flour was put into $100 \mathrm{ml}$ measuring cylinder. The measuring cylinder was then tapped continuously on a laboratory table until a constant volume was obtained. $\mathrm{BD}\left(\mathrm{g} / \mathrm{cm}^{3}\right)$ was calculated using following the formula:

\section{Weight of sample}

$$
\mathrm{BD}\left(\mathrm{g} / \mathrm{cm}^{3}\right)=\overline{\text { Volume of sample after taping }}
$$

\section{Foam Capacity (FC) and Foam Stability (FS):-}

The foam capacity (FC) and stability (FS) of flour from heart of oil palm tree were studied by the method of Coffman and Garcia (1977). $3 \mathrm{~g}$ of flour was transferred into clean, dry and graduated $(50 \mathrm{ml})$ cylinders. The flour samples were gently level and the volumes noted. Distilled water $(30 \mathrm{ml})$ was added to each sample; the cylinder was swirled and allowed to stand for $120 \mathrm{~min}$ while the change in volume was recorded every $10 \mathrm{~min}$. The FC (\%) and FS (\%) values were calculated as follows:

$$
\begin{aligned}
& \mathrm{FC}(\%)=\frac{\mathrm{V}_{\mathrm{t}}-\mathrm{V}_{0}}{\mathrm{~V}} \times 100 \\
& \mathrm{FS}(\%)=\frac{\mathrm{FC}}{\mathrm{FC}_{\mathrm{O}}} \times 100
\end{aligned}
$$

Where $\mathrm{V}_{0}(\mathrm{ml})$ is the original volume of sample, $\mathrm{V}_{\mathrm{t}}$ is the total volume after different times $(\mathrm{ml})$ and. $\mathrm{FC}_{\mathrm{O}}$ is the foam capacity at $0 \mathrm{~min}$.

Water Absorption Capacity (WAC) and Water Solubility Index (WSI):-

The water absorption capacity and solubility index of flours from heart of oil palm tree were evaluated according to Phillips et al. (1988) and Anderson et al. (1969) methods respectively. $1 \mathrm{~g}$ of flour samples $\left(\mathrm{M}_{\mathrm{o}}\right)$ was each weighed into a centrifuge tube and $10 \mathrm{ml}$ distilled water added. The content of the centrifuge tube was shaken for $30 \mathrm{~min}$ in a KS 10 agitator. The mixture was kept in a water bath (MEMMERT) $\left(37^{\circ} \mathrm{C}\right)$ for $30 \mathrm{~min}$ and centrifuged (ALDRESA, DITACEN II) at $5000 \mathrm{rpm}$ for $15 \mathrm{~min}$. The resulting sediment $\left(\mathrm{M}_{2}\right)$ was weighed and then dried at $105^{\circ} \mathrm{C}$ to constant weight $\left(\mathrm{M}_{1}\right)$. The WAC and WSI were then calculated as follows:

$$
\begin{aligned}
& \operatorname{WAC}(\%)=\frac{\mathrm{M}_{2}-\mathrm{M}_{1}}{\mathrm{M}_{1}} \times 100 \\
& \operatorname{WSI}(\%)=\frac{\mathrm{M}_{2}-\mathrm{M}_{1}}{\mathrm{M}_{1}} \times 100
\end{aligned}
$$




\section{Paste Clarity:-}

The lightness of the pastes of the flour or starch was measured according to the method of Craig et al. (1989). A mass of $0.2 \mathrm{~g}$ of sample was dissolved in $20 \mathrm{ml}$ of distilled water contained in a centrifuge tube. The mixture was homogenized by the use of a vortex and then heated in boiling water $\left(100^{\circ} \mathrm{C}\right.$.) for $30 \mathrm{~min}$. During this heating, the reaction medium was homogenized every $5 \mathrm{~min}$. After this heat treatment, the reaction medium was cooled on the bench for $10 \mathrm{~min}$. The clarity of the sample paste was determined by measuring the transmittance at $650 \mathrm{~nm}$ on the spectrophotometer against distilled water. The effect of the concentration of the sample on the clarity of the dough was also determined by repeating the procedure described above for concentrations of $2,4,6,8$ and $10 \%(\mathrm{w} / \mathrm{v}$ ).

\section{Wettability:-}

The wettability of the flours was determined according to the technique of Onwuka (2005). One (1) g of flour was placed in a $25 \mathrm{ml}$ graduated cylinder having a diameter of $1 \mathrm{~cm}$. A finger was placed on the opening of the test piece (to avoid pouring the sample by reversing it). The finger closing the specimen was placed at a height of $10 \mathrm{~cm}$ from the surface of a $600 \mathrm{ml}$ beaker containing $500 \mathrm{ml}$ of distilled water. The finger was removed and the sample was poured into the beaker. Wettability was determined to be the time required for the sample to become fully wetted.

\section{Flour dispersibility (D):-}

The flour dispersibility was determined by the method described by Kulkani et al., (1991). $10 \mathrm{~g}$ of flour were weighed into $100 \mathrm{ml}$ measuring cilynder and distilled water added to make a volume of $100 \mathrm{ml}$. The set up was stirred vigorously for $1 \mathrm{~min}$. The volume of the settled particles was registered after regular time step of $30 \mathrm{~min}$. The volume of settled particles was subtracted from 100. The difference was reported as percentage of dispersibility.

\section{Oil absorption capacity (OAC):-}

The oil capacity of flours from heart of oil palm tree was evaluated according to Eke and Akobundu (1993) methods. $1 \mathrm{~g}$ of sample $\left(\mathrm{M}_{\mathrm{o}}\right)$ was mixed with $10 \mathrm{ml}$ in a weighed $20 \mathrm{ml}$ centrifuge tube. The slurry was agitated on a vortex mixer for $2 \mathrm{~min}$, allowed to stand at $28^{\circ} \mathrm{C}$ for $30 \mathrm{~min}$ and then centrifuged at $4500 \mathrm{rpm}$ for $30 \mathrm{~min}$. The clear supernatant was decanted and discarted. The adhering drops of oil were removed and the tube was weighted $\left(\mathrm{M}_{1}\right)$. The AOC was calculated as follows:

$$
\operatorname{OAC}(\%)=\frac{\mathrm{M}_{n}-\mathrm{M}_{1}}{\mathrm{M}_{0}} \times 100
$$

\section{Statistical analysis:-}

All analyses were performed in triplicates. Results were expressed by means of \pm SD. Statistical significance was established using Analysis of Variance (ANOVA) models to estimate the physicochemical and functional properties of heart of oil palm. Means were separated according to Duncan's multiple range analysis ( $\mathrm{p} \# 0.05$ ), with the help of the software Statistica (StatSoft Inc, Tulsa USA Headquarters) (Duncan, 1955)

\section{Results and Discussion:-}

The proximate composition of different parts (PP, MP, DP) from heart of oil palm (Elaeis guineensis Jacq.) is shown in Table 1 . The physicochemical properties differ significantly $(\mathrm{p}<0.05)$ from a part to another.

Moisture content is an index of storage of the flours. Flours moisture contents $(5.87 \pm 0.01 \%$ to $10.83 \pm 1.16 \%)$ less than $14 \%$ can resist microbial growth and contribute to best storage (Colas, 1998; Okonkwo and Opara. 2010).

Ash content of the differents parts of heart of oil palm ( $6.91 \pm 0.07 \%$ to $8.28 \pm 0.51 \%$ may be considered as good sources of minerals compared to cereals and tubers values $(2-10 \%)$ (FAO, 1986).

The crudes fibers content $(21.98 \pm 0.02-34.9 \pm 0.1 \%)$ in the three parts of heart of oil palm would be advantageous for their active role in the regulation of intestinal transit (Jenkin et al., 1986 ; (Mensah et al., 2008). these contents are higher compared to vegetables studied (M. arboreus: $12.19 \pm 0.73 \%$ and $C$. argentea : $30.83 \pm 1.61 \%$ ) in Côte d'Ivoire (Zoro et al., 2013). Therefore, the consumption of heart of oil palm tree may be advantageous since high fibers content of foods help in digestion, prevention of colon cancer and in the treatment of diseases such as obesity, diabetes and gastrointestinal disorders (Saldanha, 1995; UICC/WHO, 2005). 
Fat content range between $7.57 \pm 0.1$ to $12.81 \pm 0.07 \%$ in differents parts of heart of oil palm tree. These results corroborate the findings of many authors who showed that vegetables are poor sources of fat (Ejoh et al., 1996).

Crude proteins content range between $12.56 \pm 0.65 \%$ to $13.12 \pm 0.69 \%$. The proteins content was higher compared to some vegetables such as Momordica balsamina (11.29 \%) and lower compared to Moringa oleifera (20.72\%) (Asaolu et al., 2012). Plant which produse more than $12 \%$ of protein are a good source of proteins (Ali, 2009).

Carbohydrate content (39.85 \pm 0.06 to $46.42 \pm 0.11 \%$ ), are higher than vegetables as Senna obtusfolia (20\%), Amaranthus incurvatus (23.7 \%) and Momordica balsamina (39.05\%) (Hassan and Umar, 2006).

The energy value of heart of oil palm tree flours range between $270.45 \pm 0.04$ (MP) to $333.56 \pm 0.02$ (DP) $\mathrm{Kcal} / 100 \mathrm{~g}$ is agree with general observation do on the vegetables which have low energy values (Lintas, 1992) due to their low fat content and relatively high level of moisture (Sobowale et al., 2011). With these energies values, flours from heart of oil palm tree could be used as energy in the flour poridge for infanys and children (Butte, 1996).

\section{Mineral composition:-}

The mineral composition of flours from the heart of oil palm tree (Elaeis guineensis Jacq.) presented in Table 2. Minerals are considered to be essential in human nutrition (Ibanga and Okon 2009; Valvi and Rathod 2011). They help in the maintenance of acid-base balance, to physiological stimulation and blood clotting (Hanif et al. 2006). The results showed that the heart of oil palm tree represent a potential source in mineral, notably in potassium, calcium.

The potassium content of flours from of heart of oil palm tree ranged between $1412 \pm 224.65$ (PP) to $1787.43 \pm$ $75.57 \mathrm{mg} / 100 \mathrm{~g}$ (MP) and are higher compared to the range $(300-400 \mathrm{mg} / 100 \mathrm{~g}$ ) of various species of vegetable (Anon, 2011, Ogbede et al., 2015 ) and carrot (178 mg/100g), lettuce (222 mg/100g) (Mark et al., 2013) .

Calcium contents in the differents part of heart of oil palm is shown in Table 3. Calcium is the major component of bone, assists in teeth development, necessary for blood coagulation and for the integrity of intracellular cement substances (Okaka and Okaka 2001). The content of Calcium varied of $356.37 \mathrm{mg} / 100 \mathrm{~g}$ (PP) to $881.18 \mathrm{mg} / 100 \mathrm{~g}$ (DP). This result is high than the Calcium contents of Okra varieties varying between 58.22 to $58.31 \mathrm{mg} / 100 \mathrm{~g}$ (Adetuya et al., 2011; Gemede et al., 2016).

Phosphorus contents (165.31 (MP) to 276.66 (DP) are higher than phosphorus content of Brassica oleracae var. capitata L.(26.92 mg/100g), Ossinum gratissimum (13.8mg/100g), Vernonia amygdalinai $(13.1 \mathrm{mg} / 100 \mathrm{~g})$, Telferia occidentalis $(15.08 \mathrm{mg} / 100 \mathrm{~g}),(16 \mathrm{mg} / 100 \mathrm{~g})$ in carrot, and $(22 \mathrm{mg} / 100 \mathrm{~g})$ in lettuce (Sobowale et al., 2011; Mark et al., 2013; Ogbede et al., 2015). Phosphorus is an important mineral that aids the absorption of calcium which is required for growth, maintenance of bones, teeth and muscles (Turan et al., 2003).

Daily calcium and magnesium requirements respectively of $800 \mathrm{mg}$ and $100 \mathrm{mg}$, (FAO, 2004) could be covered by the consommation of the heart of oil palm tree. As a result, the heart of oil palm tree could be recommended for feeding to children and lactating women.

Taking into account the phospho-calcium ratio $(\mathrm{Ca} / \mathrm{P})$, the proximal part of heart of oil palm tree has the value $(\mathrm{Ca} / \mathrm{P})$ closest to that recommended by FAO/WHO (2004) for food (1.82).

Iron is an essential trace element for hemoglobin formation, normal functioning of central nervous system (Ullah $e t$

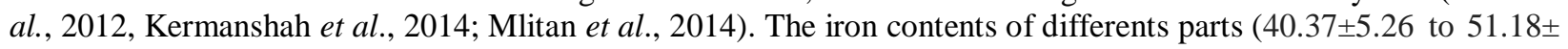
2.53) of the studied palm heart are higher than the daily requirements estimated at $8 \mathrm{mg}$ (FAO/ WHO, 2004). This iron richness would resolve important health issue in Africa, where there are many cases of anemia caused by malaria and immune deficiency (Akindahunsi and Salawu, 2005) It also facilitates oxidation carbohydrates, protein, and fat to control body weight, which is very important factor in diabetes (Moses et al., 2012).

The presence of copper and silicon in the differents parts (PP, MP, DP) studied could give an added nutritional value because these trace elements are involved in the development of brain activity and in the functioning of the nervous system (Soetan et al., 2010). 


\section{Functional properties:-}

The result presented in Table 3 showed the functional properties of the flours from heart of oil palm tree. Functional properties of food are defined as physicochemical properties reflecting complex interactions between the composition, structure, conformation and physicochemical properties components (Kohnhorst et al., 1990; Hussain et al., 2008). There could have significant differences $(\mathrm{P}<0.05)$ between the three parts flours functional properties. The bulk density (BD) is presented in table 1. BD is a measure of the weight of flour (Adejuyitan et al., 2009) which determines the suitability of a flour to be easily packaged, would facilitate the transport of a large amount of food (Shittu et al., 2005). The BD result is used to evaluate the flour heaviness, handling requirement and the type of packaging materials suitable for storage and transportation of food materials (Oppong et al., 2015). Nutritionally, low bulk density promotes the digestibility of food products, especially in children because of their immature digestive system (Nelson-Quartey et al., 2007). It has been reported that bulk density is influenced by the structure of the starch polymers and loose structure of the starch polymers could result in low bulk density (Malomo et al., 2012). The Bulk Density value of heart of oil palm tree flour range between $0.54 \pm 0.01 \mathrm{~g} / \mathrm{cm}^{3}$ to $0.57 \pm 0.01 \mathrm{~g} / \mathrm{cm}^{3}$ is similar to $0.55-0.62 \mathrm{~g} / \mathrm{cm}^{3}$ reported for tigernut (Cyoperus esculentus) seed flour (Oladele and Aina, 2007) and lower than wheat flour $\left(0.80 \mathrm{~g} / \mathrm{cm}^{3}\right.$ to $\left.0.90 \mathrm{~g} / \mathrm{cm}^{3}\right)$ and chickpea $\left(0.94 \mathrm{~g} / \mathrm{cm}^{3}\right)$ ((Ijarotimi, 2012; Jagannadham et al., 2015). Low BD is advantageous for the infants as both calorie and nutrients density in enhanced per feed of the child (Onimawo and Egbekun, 1998). The low bulk density of heart of oil palm tree flours, suggests that they may be use in formulating infant food.

Foams are used to improve texture, consistency and appearance of foods (Akubor, 2007). Results showed that foam capacity (FC) of heart of oil palm tree flours varied from $26.31 \pm 1.73 \%$ (CPPO) to $31.61 \pm 0.54 \%$ (CPMO). The FC values obtained were higher than those reported by Amon et al. (2011) in taro flour (Colocasia esculenta) Cv Yatan. Foam capacity and stability are a function of the type of protein, $\mathrm{pH}$, processing methods, viscosity and surface tension (Fekria et al., 2012). The values of FC range between $26.31 \pm 0.72 \%$ (CPPO) to $31.61 \pm 0.54 \%$ (CPMO) (Table 2). The foam capacity values of flours did not differ signicantly $(\mathrm{P}<0.05)$. The foam Capacity values were higher than those Artocarpus altilis $(14.51 \pm 1.61 \%)$ (Oulai et al., 2014), Cassava pulp flour (13.70\%) and the breadfruit kernel flour (20\%) (Akubor and Badifu, 2004, Ubbor and Akobundu, 2009). The presence of fat (7.57 to 12.81 ) in flours might be responsible for the low foaming capacity observed.

Water absorption capacity (WAC) values (453.15 $\pm 1.6 \%$ to $568.7 \pm 0,89 \%)$ were higher than the WAC values of uncooked rice (225\%), potato (277\%) and cassava (197\%) (Abulude, 2004; Nwosu et al. 2014). The presence of fat, though in small quantity, may be responsible for the moderate quantity of WAC of each of these legume samples. The relationship between the content of hydrophilic group of proteins and WAC had been established which gave the indication that legume plants rich in protein have more hydrophilic groups exposed to water (Oyebode et al., 2007; Hermanson, 2008). In addition, this result could also be explained by the destruction of the cell membranes during osmosis phenomena causing a massive entry of water into the cells. Therefore, the flours of heart of oil palm would be useful in enhancing the water binding capacity of food products like dough, sausages mayonnaise and cakes.

The water solubility index (WSI) reflects the extent of starch degradation (Diosady et al., 1985), determines the amount of free polysaccharides or released from the granule after addition of excess water (Sriburi and Hill, 2000). The flours WSI values vary significantly at the 5\% threshold. The variation in the solubility of the various flours would be related to the high water absorption caused by the disorganization of the cell walls (Tucker and Grierson, 1987). The WSI values $(25.4$ - 30.25 \%) of flours from heart of oil palm tree (Elaeis guineensis Jacq.) are higher than those of different raw flours of wheat flour $(12.3 \%)$ rice flour $(14.7 \%)$ and raw taro flours $(18 \%$ to $27 \%)$ (Mbofung et al., 2006, Kaur, 2015).

Oil absorption capacity (OAC) measures the ability of food material to absorb oil The OAC (table 2) is an important property in food formulation because fats improve the flavor and mouth feel of foods (Kinsella, 1976). They are also important because of storage stability in the rancidity development (Siddiq et al., 2010).

The low PC of the raw flour would be explained by the fact that the not swollen starch granules remaned dense reflecting the maximum of light entering the medium (Tetchi et al., 2007). Consequently, pastes were turbid or opaque as described in the literature (Craig et al., 1989). 
The paste clarity is an important property which control different applications of flour and starch for the processing of food products. The clarity study showed that there was a significant difference $(p \leq 0.05)$ between heart of oil palm flours. These values of clarity $(0.21 \mathrm{CPP} 0 ; 0.16$ CPM0 and 0.17 CPD 0$)$ are much lower than those obtained by Oulai et al., (2014) for breadfruit flours "Artocarpus altilis" (30.56\%) and by Amani (2002) for "kangba" yam flour $(42 \%)$. This small percentage of clarity can be explained by the presence of the uninflated granules of the flour in the suspension which reflected the maximum light (Tetchi et al., 2007) and on the other hand by the crude fat contents, crude protein (Craig et al., 1989), the botanical source and the ability of granules to form aggregates (Amani et al., 2005). The flours of heart the oil palm (Elaeis guineensis Jacq.) could be ideal for the salad dressing.

The wettability study showed that there is variability between hearts of oil palm flours. This difference is due to the composition of flours and to the affinity between its components and water and to the accessibility of water to flour constituents (Schuck et al., 2007). Our values are higher than those of soybean flour (31 s) and wheat (52 s) noted by Nwosu et al. (2014). Indeed, flour is said to be very wettable if the wettability time is less than 30 seconds; It is wettable if the time is less than 60 seconds. On the other hand, it is considered as non-wettable if the wettability time is greater than 120 seconds (Pohl, 2004). Thus, the CPP0, CPM0 and CPD0 flours would not be wettable and cannot be used for swelling because according to Schuck et al. (2007) flour capable of getting wet would be able to swell when handling the pasta. Indeed, the wettability of a food takes into account the balance between the cohesive forces within the liquid and the adhesion forces (Haugaard et al., 1978). Therefore, the presence of primary particles, density and porosity improve wettability (Haugaard et al., 1978). On the other hand, the presence of fat at the surface of the particles reduces or limits the wetting.

The values of flours foam stability (FS) decreases slowly during the time (120 min) (Figure 1). Reducing of foaming properties was related to protein denaturation. FS values were higher than those reported for defatted ground nut flour (4\% - 4.2\%) (Fekria et al., 2012). Flours of heart of oil palm tree has potential for application in food systems that require high percentage of porosity such as ice cream and cakes also in nonfood products as a foaming agent.

Dispersibility (D) is the ability of flour to be wet without the formation of lumps, with simultaneous disintegration of agglomerates. It gives an indication of particles suspensibility in water, which is useful functional parameter in various food products formulations (Mora-Escobedo et al 1991). The importance of dispersibility is that it indicates the reconstitution ability of the sample. In order to know how heart of oil palm flours reconstructed in water, the dispersibility test was done. After $50 \mathrm{~min}$, the dispersibility of the various parts increases and stabilized. Samples were significantly different in terms of their dispersibility. The flours dispersibility of heart of oil palm tree (55.61\% PP; $20.97 \%$ MP; $32.1 \%$ DP) are lower than the dispersibility of soy-enriched tapioca (63.0 to $87.0 \%$ ) (Otegbayo et al., 2013) and that of local rice in Nigeria (56-66\%) (Eke-Ejiofor et al., 2011) and breadfruit flour Artocarpus altilis (54\%) (Oulai et al., 2014). Furthermore, dispersibility is influenced by solubility, wettability, crude protein content, particle size profile, air temperature and reconstitution conditions (Wester-gaard, 1994). According to the standard, the milk powder is dispersible when its dispersibility index is greater than $90 \%$ (Haugaard et al., 1978). Therefore, the dispersibility values of heart of oil palm flours recorded after 60 min are less than 90, which is why they are not dispersible. The water solubility index (WSI) reflects the extent of starch degradation (Diosady et al., 1985).

Oil absorption capacity (OAC) presented in figure 3 measures the ability of food material to absorb oil. The flours from heart of oil palm tree showed moderate oil absorption capacity (OAC). The OAC values of flours ranged from 72.95 to $87.35 \%$ (PP), 75.35 to $93.25 \%$ (MP) and 84.7 to $100.05 \%$ (DP). These values were lower than Artocarpus altilis flour (139\%), breadfruit (150\%) and ground nut flour (287\% and $293 \%$ ) (Appiah et al., 2001, Fekria et al., 2012, Oulai et al., 2014). The low OAC means the flour could be used as a coating in deep fat frying to reduce oil absorption by the fried food. Interactions of water and oil with proteins are very important in food systems because of their effects on the flavor and texture of foods (Amadou et al., 2010). Fekria et al., (2012) reported that the ability of the flour to absorb and retain water and oil may help to improve the binding capacity and enhance flavor retention, improve mouthfeel and reduce moisture.

Table 1:- Proximate composition of flours from heart of oil palm tree (Elaeis guineensis Jacq.).

\begin{tabular}{|l|c|c|c|}
\hline \multirow{2}{*}{ Parameters (\%) } & \multicolumn{2}{|c|}{ Flours } \\
\cline { 2 - 4 } & PP & MP & DP \\
\hline Moisture & $5.87 \pm 0.01^{\mathrm{b}}$ & $10.83 \pm 1.16^{\mathrm{a}}$ & $8.82 \pm 0.27^{\mathrm{a}}$ \\
\hline Ash & $8.28 \pm 0.51^{\mathrm{a}}$ & $6.91 \pm 0.07^{\mathrm{b}}$ & $8 \pm 0.06^{\mathrm{a}}$ \\
\hline
\end{tabular}




\begin{tabular}{|l|c|c|c|}
\hline Acidity $($ meq/100g) & $5.64 \pm 0.6^{\mathrm{a}}$ & $4.93 \pm 0.61^{\mathrm{a}}$ & $4.58 \pm 0.61^{\mathrm{a}}$ \\
\hline $\mathrm{pH}$ & $5.79 \pm 0.01^{\mathrm{a}}$ & $6.09 \pm 0.01^{\mathrm{c}}$ & $5.90 \pm 0.01^{\mathrm{b}}$ \\
\hline Total sugars $(\mathrm{g} / 100 \mathrm{~g})$ & $30.45 \pm 3.25^{\mathrm{b}}$ & $96.68 \pm 0.31^{\mathrm{a}}$ & $96.64 \pm 0.14^{\mathrm{a}}$ \\
\hline Reducing sugars $(\mathrm{g} / 100 \mathrm{~g})$ & $0.02 \pm 0,00^{\mathrm{b}}$ & $0.05 \pm 0,00^{\mathrm{a}}$ & $0.02 \pm 0,00^{\mathrm{b}}$ \\
\hline Carbohydrate & $39.85 \pm 0.06^{\mathrm{a}}$ & $39.88 \pm 0.02^{\mathrm{a}}$ & $46.42 \pm 0.11^{\mathrm{b}}$ \\
\hline Crude fiber & $26.49 \pm 0.13^{\mathrm{a}}$ & $34.9 \pm 0.1^{\mathrm{b}}$ & $21.98 \pm 0.02^{\mathrm{a}}$ \\
\hline Crude fat & $12.81 \pm 0.07^{\mathrm{c}}$ & $7.57 \pm 0.1^{\mathrm{a}}$ & $10.61 \pm 0.05^{\mathrm{b}}$ \\
\hline Crude protein & $12.56 \pm 0.65^{\mathrm{ab}}$ & $10.7 \pm 0.66^{\mathrm{a}}$ & $13.12 \pm 0.69^{\mathrm{b}}$ \\
\hline Energy $(\mathrm{Kcal} / 100 \mathrm{~g})$ & $324.93 \pm 0.02^{\mathrm{c}}$ & $270.45 \pm 0.04^{\mathrm{a}}$ & $333,65 \pm 0.01^{\mathrm{b}}$ \\
\hline
\end{tabular}

Mean values with different superscripts within a column are significantly different $(\mathrm{p}<0.05)$. PP: Proximal Part; MP: Median Part, DP: Distal Part.

Table 2:- Mineral composition of flours from heart of oil palm tree (Elaeis guineensis Jacq.).

\begin{tabular}{|l|l|l|c|}
\hline \multirow{2}{*}{ Minerals (mg /100g DM) } & \multicolumn{1}{|c|}{ PP } & \multicolumn{1}{|c|}{ MP } & DP \\
\cline { 2 - 4 } & \multicolumn{1}{|c|}{ PP } & $881.18 \pm 63.08^{\mathrm{c}}$ \\
\hline Calcium & $356.37 \pm 3.16^{\mathrm{a}}$ & $522.29 \pm 12.03^{\mathrm{b}}$ & $433.61 \pm 16.72^{\mathrm{c}}$ \\
\hline Magnesium & $208.45 \pm 8.73^{\mathrm{a}}$ & $316.73 \pm 29.20^{\mathrm{b}}$ & $276.66 \pm 21.53^{\mathrm{b}}$ \\
\hline Phosphorus & $193.98 \pm 7.18^{\mathrm{a}}$ & $165.31 \pm 7.03^{\mathrm{a}}$ & 3.18 \\
\hline Potassium & $1494.57 \pm 74.73^{\mathrm{ab}}$ & $1787.43 \pm 75.57^{\mathrm{b}}$ & $1412 \pm 224.65^{\mathrm{a}}$ \\
\hline Ca/P & 1.83 & 3.16 & $51.18 \pm 2.53^{\mathrm{a}}$ \\
\hline Iron & $40.37 \pm 5.26^{\mathrm{b}}$ & $47.27 \pm 4.1^{\mathrm{a}}$ & $12.58 \pm 3.54^{\mathrm{a}}$ \\
\hline Copper & $10.23 \pm 2.53^{\mathrm{a}}$ & $12.14 \pm 3.13^{\mathrm{a}}$ & $18.72 \pm 2.68^{\mathrm{a}}$ \\
\hline Silicon & $14.72 \pm 4.10^{\mathrm{a}}$ & $16.08 \pm 8.29^{\mathrm{a}}$ & $2.05) . P P$ \\
\hline
\end{tabular}

Mean values with different superscripts with in a column are significantly different ( $\mathrm{p}$ 0.05). PP: proximal part; MP : median part, DP : distal part. DM: Dry Matter.

Table 3:- Functional properties of flours from heart of oil palm tree (Elaeis guineensis Jacq.)

\begin{tabular}{|l|ccc|}
\hline \multirow{2}{*}{$\begin{array}{l}\text { Functional } \\
\text { Properties }(\%)\end{array}$} & \multicolumn{3}{|c|}{ Flours } \\
\cline { 2 - 4 } & PP & MP & DP \\
\hline Bulk Density $\left(\mathrm{g} / \mathrm{cm}^{3}\right)$ & $0.54 \pm 0.01^{\mathrm{a}}$ & $0.56 \pm 0.01^{\mathrm{a}}$ & $0.57 \pm 0.01^{\mathrm{a}}$ \\
\hline Foam Capacity & $26.31 \pm 0.72^{\mathrm{b}}$ & $31.61 \pm 0.54^{\mathrm{a}}$ & $31 \pm 1.41^{\mathrm{a}}$ \\
\hline WAC & $453.15 \pm 1.6^{\mathrm{a}}$ & $534.58 \pm 0,2^{\mathrm{b}}$ & $568.70 \pm 0,89^{\mathrm{c}}$ \\
\hline WSI & $27.8 \pm 0.42^{\mathrm{b}}$ & $30.25 \pm 0.21^{\mathrm{c}}$ & $25.4 \pm 0.28^{\mathrm{a}}$ \\
\hline Paste Clarity & $0.21 \pm 0.00^{\mathrm{b}}$ & $0.16 \pm 0.00^{\mathrm{a}}$ & $0.17 \pm 0.01^{\mathrm{a}}$ \\
\hline Wettability $(\mathrm{sec})$ & 135.9 & 230 & 330 \\
\hline
\end{tabular}

Mean values with different superscripts within a column are significantly different $(\mathrm{p}<0.05)$. PP: Proximal Part ; MP : Median Part, DP : Distal Part.

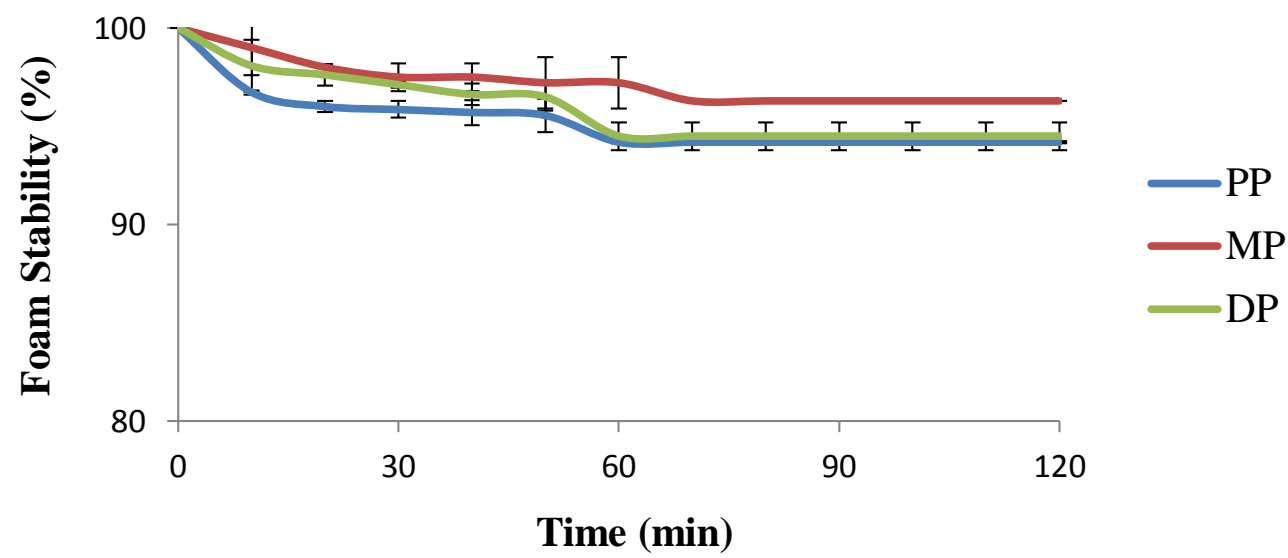

Figure 1:- Foam stability of flours from heart of oil palm tree (Elaeis guineensis Jacq.). 


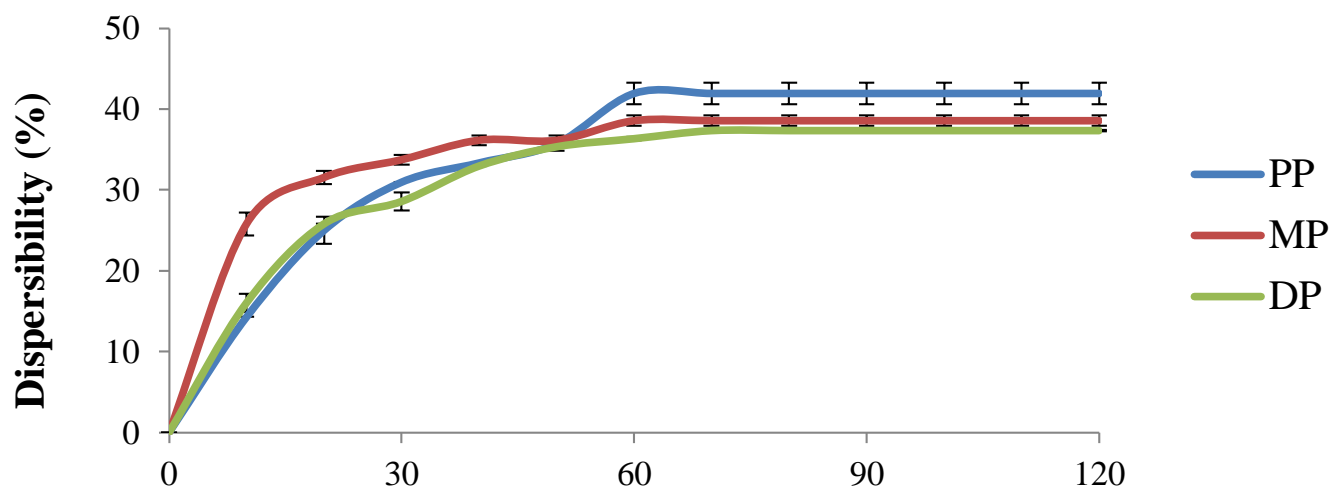

Time (min)

Figure 2:- Dispersibility of flours from heart of oil palm tree (Elaeis guineensis Jacq.)

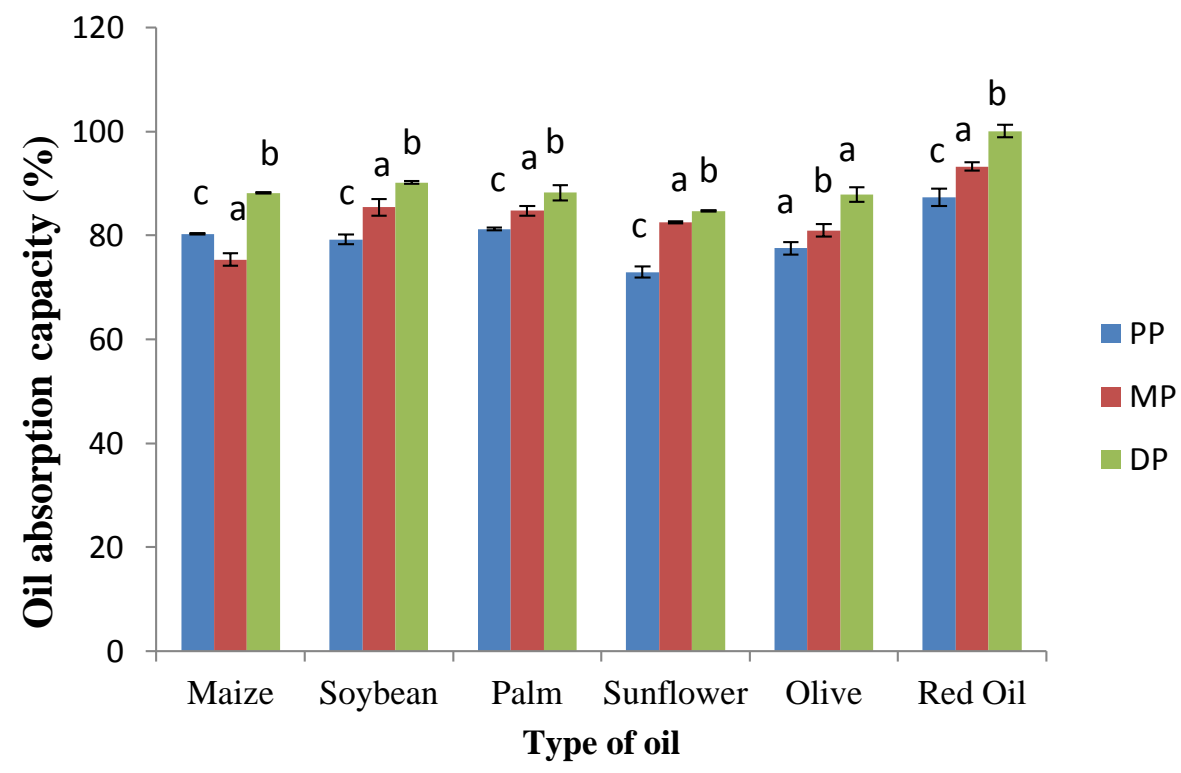

Figure 3:- Oil Absorption Capacity (OAC) of various oils of flours from the heart of oil palm tree (Elaeis guineensis Jacq.)

\section{Conclusion:-}

The conducted study revealed that the flours from heart of oil palm tree are a good source of ash, total sugars, carbohydrate, crude fiber, energy value and potassium hence their interest in the use of human diet. The low moisture content which makes them store for a long time. Therefore, it would be wise to cook heart of oil palm tree before eating. The low moisture content which makes them store for a long time. Therefore, it would be wise to cook heart of oil palm tree before eating. Then high Water absorption capacity (WAC) of flours from heart of oil palm tree was good providing agent and can thus used as a thickener or gelling agent in various food. The low bulk density (BD) were as well as the high solubility, so heart of oil palm flours would be useful in infant meals formulation. The functional properties of flours from heart of oil palm tree are also a promotion to be used in food formulation

\section{Acknowledgements:-}

This work was supported by Ph.D. grant to the first author. The authors are grateful to Laboratory of Biocatalysis and Bioprocessing at the University Nangui Abrogoua (Abidjan, Côte d'Ivoire) for technical assistance. 


\section{References:-}

1. Abulude, F.O. (2004). Effects of processing on nutritional composition, phytate and functional properties of rice (Oryza sativa) flour. Nig Food J. 22: 97-104.

2. Adejuyitan, J.A. Otunola, E.T. Akande, E.A. Bolarinwa, I.F and Oladokun, F.M. (2009). Some physicochemical properties of flour obtained from fermentation of tigernut (Cyperus esculentus) sourced from a market in Ogbomoso, Nigeria. Afr J Food Sci. 3: 51-55.

3. Adetuyi, F. O., A. U. Osagie, and A. T. Adekunle. 2011. Nutrient, antinutrient, mineral and bioavailability of okra Abelmoschus esculentus (L) Moench. Am. J. Food Nutr. 1:49-54.

4. Akindahunsi A.A. and Salawu S.O. (2005). Phytochemical screening and nutrient antinutrient composition of selected tropical green leafy vegetables. Afr. J. Biotechnol., 4: 497-501.

5. Akubor, P.I. (2007). Chemical, functional and cookie baking properties of soybean / maize flour blends. $J$ Food Sci Technol. 44: 619-622.

6. Akubor, P.I. and Badifu, G.I.O. (2004). Chemical composition, functional properties and baking potential of African breadfruit kernel and wheat flour blends. Int J Food Sci Tech. 39: 223-229.

7. Ali, A. (2009). Proximate and mineral composition of the marchubeh (Asparagus officinalis). World Dairy Food Science., 4: 142-149.

8. Amadou, I., Amza, T., Foh, M.B.K., Kamara, M.T. and Le, G.W. (2010) Influence of Lactobacillus plantarum Lp6 Fermentation on the Functional Properties of Soybean Protein Meal. Emirates Journal of Food and Agriculture, 22, 456-465. http://dx.doi.org/10.9755/ejfa.v22i6.4663

9. Amani, N.G. Kamenan, A. Sabaté, and Colonna, A.P. (2005). Stability of yam starch gels during processing. Afr J Biotechnol. 4: 94-101.

10. Amon A.S., Soro, R.Y., Koffi, B.K.P., Dué A.E., and Patrice Kouamé P.L., (2011). Biochemical Characteristics of Flours from Ivorian Taro (Colocasia Esculenta, $\mathrm{Cv}$ Yatan) Corm as Affected by Boiling Time. Advance Journal of Food Science and Technology 3(6):424-435

11. Anderson, R.A. Conway, H.F. Pfeifer, V.F. and Griffin, E.L. (1969). Roll and extrusion-cooking of grain sorghum grits. Cer SciToday. 14: 372-380.

12. AOAC. (1990). Official Methods of Analysis 14 th édition, Association of official analytical chemists. Washington, DC, $150 \mathrm{p}$.

13. Appiah, F. Oduro, I. and Ellis, W.O. (2011b) . Functional properties of Artocarpus altilis pulp flour as affected by Fermentation. Agric Biol J N Am. 2: 773-779.

14. Asaolu, S.S., O.S. Adefemi, I.G. Oyakilome, K.E. Ajibulu and M.F. Asaolu, (2012). Proximate and mineral composition of Nigerian leafy vegetables. J. Food Res., 3: 214-218.

15. Asaolu, S.S., O.S. Adefemi, I.G. Oyakilome, K.E. Ajibulu and M.F. Asaolu, (2012). Proximate and mineral composition of Nigerian leafy vegetables. J. Food Res., 3: 214-218.

16. Butte, N.F. (1996). Energy requirements of infnats. Europen Journal of Clinical Nutrition 50 :24-36.

17. CIRAD [Internet]. Centre de Coopération Internationale en Recherche Agronomique. 2017 [cite en 201728 Septembre]. (Sources: Cirad, Université de Sherbrooke Perspectives Monde ).

18. Coffman, C.W.L. and Garcia, V.C. (1977). Functional properties and amino acid of a protein isolate from mungbean flour. J Food Technol. 12: 473-484.

19. Colas, A. (1998). Definition de la qualité des farines pour les differentes utilisations. In, Gordon B, Will M.C. Les industries de première transformation des céréales. Lavoisier, tec et doc/apria.Paris 679 p.

20. Craig, S.A.S. Maningat, C.C. Seib, P.A. and Hoseney, R.C. (1989). Starch paste clarity. Cereal Chem. 66:173 182.

21. Depezay, L. (2006). Les légumes dans l'alimentation: leurs effets nutritionnels. Fondation Louis Bonduelle Ed., $7 \mathrm{p}$.

22. Diosady, L.L., Paton, D.R.N., Rubin, L.T and Athanassoulias, C.(1985). Degradation of wheat starch in a singlescrew extrader : Mechano-kinetic breakdown of cooked starch. J Food Sci.50:1703

23. Dubois M., Gruillies K., Hamilton J., Rogers P. and Smith F. (1956). Colorimetric method for determination of sugars and related substances. Analytical Chemistry, 28: 350-356.

24. Duncan D. B. (1955). Multiple range and Multiple F-tests, Biometrics. 11, 1-42

25. Ejoh, A.R., Tchouanguep, M.F. and Fokou, E., (1996). Nutrient composition of the leaves and flowers of Colocasia esculenta and the fruits of Solanum melongena. Plant Food Hum. Nutr., 49: 107-112.

26. Eke, O.S., and Akobundu, E.N.T. (1993). Functional properties of African yam bean (Sphenostylis stenocarpa) seedflour as affected by processing. Chemical, 48:337-340

27. FAO, (1986). Food composition table for use in Africa. FAO Ed, Rome, Italy.

28. FAO, (2002). Food energy-methods of analysis and conversion factors. FAO Ed, Rome, 97. 
29. FAO, (2004) : Mission d'évaluation des récoltes et des disponibilités alimentaires en Côte d'Ivoire. Système mondial d'information et d'alerte rapide (SMIAR-FAO)

30. FAO STAT (2013). Bilans alimentaire: production mondiale de l'huile de palme. Division de la Statistique, FAOSTAT, Série informatique, FAO, Rome, Italie.

31. Fekria, A.M., Isam, A.M.A., Suha, O.A. and Elfadil, E.B. (2012). Nutritional and Functional Characterization of Defatted Seed Cake Flour of Two Sudanese Groundnut (Arachis hypogaea) Cultivars. International Food Research Journal, 19, 629-637.

32. Grivetti L., Frentzel C., Ginsberg K., Howell K., Ogle B. (1987). Bush foods and edible weeds of agriculture: perspectives on dietary use of wild plants in Africa, their role in maintaining human nutritional Status and implications for agricultural development. In: Akhtar, R. (ed.): Health and disease in tropical Africa. Harwood, London: 51-81 p.

33. Habtamu, F.G., Gulelat, D.H., Fekalu, B., Ashagrie, Z.W. and Sudip, K.R. (2015). Proximate, mineral, and nutrtition compositions of indigenous Okra (Abelmoschus esculenta) pod accessions : implications for mineral bioavailability. Food Science and Nutrition, 4(2) :223-233.

34. Hanif, R., Z. Igbal, M. Igbal, S. Hanif, and M. Rasheed. 2006. Use of vegetables as nutritional food: role in human health. J. Agric. Biol. Sci. 1:18-20.

35. Hassan, L.G. and K.J. Umar, 2004. Antinutritive Factors in African Locust Beans (Parkia biglobosa). Proceedings of the 27 International Conference, Nigeria, pp. 322-326.

36. Haugaard- Sorensen I., Krag J., Pisecky J., Westergaard V. (1978). Méthodes d'analyses des produits laitiers déshydratés, Niro A/S (édition), Copenhagen, Danemark, 109 p.

37. Hermanson, A. M. (2002). Functional properties of protein for food swelling lebensin. Wiss. Technol. 51: 24.

38. Hubert O : (2010). Contribution de la production d'huile de palme au développement durable.

39. Oléagineux, Corps gras, Lipides, 17(6) : 362- 367.

40. Hsu C-L., Chen W., Weng Y-M \& Tseng C-Y. (2003). Chemical composition, physical properties, and antioxidant activities of yam flours as affected by different drying methods. Food Chemistry 83: 85-92.

41. Hussain, S., Anjum, F.M., Butt, M.S. and Sheikh, M.A. (2008) Chemical Compositions and Functional Properties of Flaxseed Flour. Sarhad Journal of Agriculture, 24, 649-653.

42. Ibanga, O. I., and D. E. Okon. 2009. Minerals and antinutrients in two varieties of African pear (Dacryodes edulis). J. Food Technol. 7:106-110.

43. Ijarotimi O.S. (2012). Influence of germination and fermentation on chemical composition, protein quality and physical properties of wheat flour (Triticum aestivum). Journal of Cereals and Oil seeds 3: 35-47.

44. UICC/WHO, 2005. Global action against cancer. UICC and WHO Publications Department, Geneva.

45. Jacquemard, J-C., (2012). Le palmier à huile; Ed Quae, Collection agriculture tropicale en poche .240p

46. Jenkin, D.J., Jenkin, A.L., Wolever, T.M.S, Rao A.V., Thompson L.U. (1986). Fibre and starchy foods: function and implication in disease. American Journal of Gastroenterology, 81: 920-930.

47. Kaur, H., De Muyt A., and Lichten M (2015). Top3-Rmi1 DNA single-strand decatenase is integral to the formation and resolution of meiotic recombination intermediates. Molecular Cell. ; 57(4):583-94.

48. Kermanshah, A., P. Ziarati, J. Asgarpanah, and M. Qomi. 2014. Food values of two endemic wild Almond species from Iran. Int. J. Plant Anim. Environ. Sci. 4:380-388.

49. Kinsella, J.E. (1976) Functional properties of proteins in foods. Critical Reviews in Food Science and Nutrition 1(3): 219-280.

50. Kohnhorst, A.L., Uebersex, M.A., Zabik, M.E. (1990). Production and functional characteristics of protein concentrates .Journal of the American Oil Chemist's Society, Volume 67(5):285-292;

51. Kulkarni K.D., Kulkarni D.N., Ingle U.M. (1991). Sorghum malt-based weaning formulations. Preparation, functional properties, and nutrictive value. Food Nutr Bull., 13: 322-327.

52. Lintas, C., (1992). Nutritional aspects of fruits and vegetable consumption. Options Meditérraneennes, 19: 7987.

53. Malomo O., Ogunmoyela O.A.B., Adekoyeni O.O., Jimoh O., Oluwajoba S.O. and Sobanwa M .O. (2012). Rheological and functional properties of soy-poundo yam flour. International Journal of Food Science and Nutrition Engineering 2(6): 101-107.

54. Mark, R., Church, S. , Pinchen, H and Finglas, P (2013). Nutrient analysis of fruit and vegetables. Analytical report, 24-29.

55. Mbofung C.M.F., Aboubakar N.Y., Njintang A., Bouba A., Balaam, F. (2006). Physicochemical and functional properties of six varieties of taro (Colocasia esculenta L.) flours. J Food Technol. 4: 135- 142.

56. Mensah J.K., Okoli R.I., Ohaju-Obodo J.O. and Eifediyi K. (2008). Phytochemical, nutritional and medical properties of some leafy vegetables consumed by Edo people of 
57. Nigeria. Afr. J. Biotechnol., 7: 2304-2309.

58. Mlitan, A.M., Sasi, M.S., and Alkhernaz, A.M (2014). Proximate and minor mineral content in some selected basil leaves of Ocimum gratissimum L., in Libya. Int .J. Chem.Eng Appl, 5 :8-17.

59. Mora-Escobedo, R. Lopez, O.P. Lopez, G.F.G. (1991). Effect of germination on the rheological and fonctional properties of amaranth sedes. Lebensm Wiss Technol., 24: 241-244.

60. Moses, G., Gitu, E.G.L., and Rotich, H. (2012). Profile of heavy metals in selected medicinal plants used for the treatment of diabetes, malaria and pneumonia in Kisii region, southwest Kenya. Global J.Pharmacol, 6:245-251

61. Nelson-Quartey F.C., Amagloh F.K., Oduro I and Ellis W.O. (2007). Formulation of an infant food based on breadfruit (Artocarpus altilis) and breadnut (Artocarpus camansi). Acta Horticulturae (ISHS) 757: $212-224$.

62. Nwosu, Justina N. Owuamanam C. I, Omeire G. C. \& Eke C. C, (2014). Quality parameters of bread produced from substitution of wheat flour with cassava flour using soybean as an improver. American Journal of Research Communication, 2 (3) : 99-118.

63. Ogbede, .C., Saidu, A.N., Kahiru, A.Y. and Busari, M.B (2015). Nutrient and anti-nutrient compositions of Brassica oleraceae Var. Capitala L. IOSR. Journal of Pharmacy.5(3) :19-25.

64. Okala, J.C. and Okala, A.N.O. (2001). Food composition, spoilage and shelf life extension, ocjarc. Academic Publishers, Enugu, Nigeria. 54-56.

65. Oladele, A.K. and Aina, J.O. (2007) Chemical Composition and Functional Properties of Flour Produced from Two Varieties of Tigernut (Cyperus esculentus). African Journal of Biotechnology, 6, 2473-2476.

66. Onimawo, I.A and Akubor, P.I. 2012. Food Chemistry (Integrated Approach with Biochemical background).2nd ed. Joytal printing press, Agbowo, Ibadan, Nigeria.

67. Okonkwo, S.L and Opara, M.F. (2010). The analysis of bambara nut (Voandzeia subterranea L.) for sustainability in Africa. Research Journal of Applied Sciences, 5 :394-396.

68. Onwuka G. (2005). Food Analysis and Instrumentation: Theory and Practice, 1st edition,

69. Naphtali Prints, Lagos, Nigeria, 129 p.

70. Oppong, D., Arthur, E., Kwadwo, S. O., Badu, E., \& Sakyi, P. (2015). Proximate composition and some functional properties of soft wheat flour. Int. J. Innovative Res. Sci. Eng. Tech., 4, 753-758.

71. Oulaï, S.F. Gonnety, J.T. Faulet, B.M. Djè, K.M. Kouassi-Koffi, J.D. Ahi, A.P. Kouamé, L.P. (2013). Effect of cooking time on the proximate and mineral composition of breadfruit (Artocarpus altilis) Grown in Abidjan, Côte D'ivoire. Pak J of Nutr. 12: 768-774.

72. Otegbayo, B.O., Samuel, F.O. and Alalade, T. (2013). Functional properties of soy-enriched tapioca Academic African Journal of Biotechnology Vol. 12(22) : 3583-3589

73. Oulaï S. F., Ahi A. P., Kouassi-Koffi J. D., Gonnety J. T., Faulet B. M., Djè M. K. and Kouamé L. P. (2014). Treatments effects on functional properties of breadfruit (Artocarpus altilis) pulp flour harvested in Côte d'Ivore, International Journal of Recent Biotechnology. 2, 1-12

74. Oyebode, E. T., Ojo, M. A. and Oshodi, A. A. (2007). Physico chemical properties and in-vitro protein digestibility of flours and protein isolate from Adenopus breviflorus Benth seed.

75. Science Focus, Vol. 12 (1), Pp. 28-34.

76. Phillips, R.D. Chinnan, M.S. Branch, A.L. Miller, J. and Mcwatters, K.H. (1988). Effects of pretreatment on functional and nutritional properties of cowpea meal. J Food Sci., 53: 805-809.

77. Shad Ma, Nawaz Hr, and Ikram N. (2013). Determionation of some biochemicals, phytochemicals and antioxidant properties of different parts of Cichorium intybus L: a comparative study. J Anim Plant Sci., 23:1060-1066.

78. Saldanha, L.G., (1995). Fibre in the diet of U.S. Children: results of national surveys. Pediat., 96: $994-996$.

79. Schuck, P., Méjean, S., Dolivet, A., Banon, S., Gaiana, C., Scher, J., and Jeantet, R. (2007).Water transfer during rehydration of micelir casein powder. Le Lait. $87 \mathrm{p}$

80. Shittu, T.A. Sanni, L.O. Awonorin, S.O. Maziya-Dixon, B. Dixon, A. (2005). Use of multivariate techniques in studying flour making characteristics of some Cassava Mosaic Disease resistant cassava clones. African Crop Sci Con Proceedings. 7: 621-630.

81. Siddiq, M. Ravi, R. Harte, J.B. Dolan, K.D. (2010). Physical and functional characteristics of selected dry bean (Phaseolus vulgaricus (L.) flours. LWT-J Food Sci Tech. 43: 232-237.

82. Sobowale, S.S., O.P. Olatidoye, O.O. Olorode and J.V. Akinlotan, (2011). Nutritional potentials and chemical value of some tropical leafy vegetables consumed in south west Nigeria J. Sci. Multidisciplinary Res., 3: 55-65.

83. Soetan, K. O., C. O. Olaiya, and O. E. Oyewole. 2010. The importance of mineral elements for humans, domestic animals and plants: a review. Afr. J. Food Sci. 4:200-222.

84. Sriburi, P.; Hill, S.E. (2000). Extrusion of cassava starch with either variation in ascorbic acid 421 concentration of $\mathrm{pH}$. International Journal of Food Science and Technology, 35, 141-154. 
85. Tabora P. C., Balick M.S., Bovi M.L.A. and Guerra M.P. (1993). Hearts of palm (Bactris, Euterpe and others). Pulse andvegetables. Edited by J.T.Williams. Published by Chapman et Hall, 2-6 Boundary Row London SE.1 8HN. JSBN 0412466104

86. Tetchi, F.A. Amani, N.G. Kamenan, A. (2007). Contribution to light transmittance modelling in starch media. Afr J Biotechnol. 6: 569-575.

87. Tucker G., Grierson D. (1987). Fruit ripening In: Davies the biochemistry of plants. A comprehensive treatise, Physiology of Metabolism. London, Academic Press, 12: 265-319.

88. Turan, M., Kordis, S., Zeyin, H., Dursan, A., and Sezen, Y. (2003). Macro and micro minerals content of some wild edible leaves consumed in eastern Anatolia. Tailors and Francis, 129-130.

89. Ubbor, S.C. Akobundu, E.N.T. (2009). Quality Characteristics of Cookies from Composite Flours of Watermelon Seed, Cassava and Wheat. Pak J Nutr., 8: 1097-1102.

90. Udosen, E.O.(1995). Proximate and mineral composition of some Nigerian vegetables, Discov.Innov,7(4) : 383386.

91. Ullah, R. J. A., I. Khader, N. M. Hussain, A. M. Talha, and N. Khan. 2012. Investigation of macro and micronutrients in selected medicinal plants". Afr. J. Pharm. Pharmacol. 69:1829-1832.

92. Valvi, S. R., and V. S. Rathod. 2011. Mineral composition of some wild edible fruits from Kolhapur district. Int. J. Appl. Biol. Pharmaceut. Technol. 2:112-119.

93. Yasumatsu, K. Sawada, K. Moritaka, S. Mikasi, M. Toda, J. Wada, T. Ishi, K. (1972). Whipping and emulsifying properties of soybean products. Agric Biol Chem., 36: 719-727.

94. Zoro A.F., Zoue L.T., Kra A.K. S., Yepie E. A. and Niamke L. S. (2013). An Overview of Nutritive Potential of Leafy Vegetables Consumed in Western Côte d'Ivoire . Pakistan Journal of Nutrition 12 (10): 949-956, 2013. 